\title{
Relationships Between Early Wheat Streak Mosaic Severity Levels and Grain Yield: Implications for Management Decisions
}

\author{
F. Workneh, ${ }^{\dagger}$ Texas A\&M AgriLife Research, Bushland, TX 79012; S. O’Shaughnessy and S. Evett, USDA-ARS, Bushland, TX 79012; \\ and C. M. Rush, Texas A\&M AgriLife Research, Bushland, TX 79012
}

\begin{abstract}
Wheat streak mosaic (WSM) caused by Wheat streak mosaic virus, which is transmitted by the wheat curl mite (Aceria tosichella), is a major yieldlimiting disease in the Texas High Plains. In addition to its impact on grain production, the disease reduces water-use efficiency by affecting root development. Because of the declining Ogallala Aquifer water level, water conservation has become one of the major pressing issues in the region. Thus, questions are often raised as to whether it is worthwhile to irrigate infected fields in light of the water conservation issues, associated energy costs, and current wheat prices. To address some of these questions, field experiments were conducted in 2013 and 2016 at two separate locations to determine whether grain yield could be predicted from disease severity levels, assessed early in the spring, for potential use as a decision tool for crop management,

including irrigation. In both fields, disease severity assessments started in April, using a handheld hyperspectral radiometer with which reflectance measurements were taken weekly in multiple plots in arbitrarily selected locations across the fields. The relationship between WSM severity levels and grain yield for the different assessment dates were determined by fitting reflectance and yield values into the logistic regression function. The model predicted yield levels with $\mathrm{r}^{2}$ values ranging from 0.67 to $0.85(P<0.0001)$, indicating that the impact of WSM on grain yield could be fairly well predicted from early assessments of WSM severity levels. As the disease is normally progressive over time, this type of information will be useful for making management decisions of whether to continue irrigating infected fields, especially if combined with an economic threshold for WSM severity levels.
\end{abstract}

In the Texas Panhandle, hard red winter wheat is cultivated as a dualpurpose crop (for grain production and winter forage for cattle grazing) on approximately three million acres annually, of which about one-third is irrigated. In this region, wheat streak mosaic (WSM) caused by Wheat streak mosaic virus (WSMV), which is transmitted by the wheat curl mite (WCM, Aceria tosichella Keifer), is a major constraint on wheat production. Infected plants exhibit mosaic and chlorotic streaks on leaves, which are followed by plant stunting and death when infection occurs early in the season. The disease is observed annually, with occasional widespread epidemics in which significant portions of affected fields are entirely decimated, producing little or no grain.

Wheat planting season in the Texas Panhandle runs from late August through November and harvest begins in mid-June. Fields planned for grazing are normally planted earlier in the season (late August to mid-September) to maximize forage production for winter grazing. However, wheat fields planted early are more vulnerable to infection by WSMV because of the abundance of native green grasses and volunteer wheat supporting mite populations which serve as a green bridge between wheat seasons (Bowden et al. 1991; Christian and Willis 1993; Connin 1956; Hunger et al. 1992; Price 2015; Thomas et al. 2004). Eradication of volunteer wheat is currently the primary tactic recommended for control of the disease (Bowden et al. 1991; Christian and Willis 1993; Connin 1956; Thomas et al. 2004). The mites are typically blown by wind into wheat fields from the surrounding grass vegetation or from nearby volunteer wheat fields, and disease symptoms are often first observed on field edges. In fields planted early, primarily for grazing, it is not uncommon to see disease symptoms in the fall before winter dormancy. In the spring when the crop breaks dormancy and temperatures become more conducive for mite reproduction and disease development, mite populations increase and the disease progresses over time across the field, resulting in a declining severity gradient (Workneh et al. 2009). Currently there are no registered pesticides for control of the WCM; thus, once the disease starts, there is nothing

${ }^{\dagger}$ Corresponding author. E-mail: f-workneh@tamu.edu

Accepted for publication 24 May 2017.

C) 2017 The American Phytopathological Society the grower can do to stop the progression. There are cultivars with resistance genes against the virus but these genes are temperature dependent, and above $27^{\circ} \mathrm{C}$ they become ineffective (Price et al. 2014; Seifers et al. 1995, 2007). For this reason, these cultivars are not widely used in the Texas Panhandle, where temperatures during the early wheat planting season routinely exceed $27^{\circ} \mathrm{C}$. The WCM can complete its life cycle (egg to adult) in 7 to 10 days, and with such a short life cycle it is not surprising that the disease can spread through the field within a season (Staples and Allington 1956, as cited by McMechan et al. 2014).

The wheat curl mite also transmits Triticum mosaic virus (TriMV) and High Plains wheat mosaic virus (HPWMoV) (Fuentes-Bueno et al. 2011; Jensen et al. 1996; Seifers et al. 1997, 2008; Skare et al. 2006), and it is not uncommon to detect all three viruses in a single infected sample. Symptoms caused by these viruses are often difficult to distinguish under field conditions. However, in the Texas Panhandle, as with the rest of the High Plains region, although all viruses can be detected occasionally in the same sample, WSMV is the most singly and frequently encountered wheat virus (Burrows et al. 2009; Byamukama et al. 2013; Workneh et al. 2008).

Wheat streak mosaic not only affects grain yield but also reduces crop water-use efficiency (Price et al. 2010; Workneh et al. 2010). Infected plants have significantly less root biomass than uninfected plants, reducing water uptake ability (Pradhan et al. 2015). Hence, infected areas of the field usually end up having greater soil moisture content than uninfected areas, and values of soil moisture content across the field is highly correlated to that of disease intensity (Workneh et al. 2010). Its impact on crop water-use efficiency has significant implications for irrigated wheat in the region, in light of the dwindling water resources and energy costs.

The High Plains region of the U.S., including the Texas Panhandle, is dependent on the Ogallala Aquifer for the majority of its water resources (agricultural irrigation, municipal consumption, and all other practical uses). However, water levels of the Ogallala Aquifer have been declining for decades because the amount of withdrawals has exceeded recharges (McGuire 2006; Scanlon et al. 2010). This has resulted in increased pumping costs and created concerns over the future of water resources for the region. Research is currently underway in various disciplines (supported by the USDA-ARS Ogallala Aquifer Program) to find ways of reducing withdrawals and, with the current low price of wheat, growers are questioning whether it is worthwhile to irrigate and add other inputs to infected fields. 
It has long been known that the earlier in the season that infection occurs, the greater the impact on final yield (Hunger et al. 1992; Price 2015). Plants that are infected and become symptomatic before winter dormancy have extremely low yield potential and frequently die. However, the impact on yield of disease that first expresses itself early in the spring is not well understood. Since the majority of crop inputs such as insecticide applications, layby fertilization, and multiple irrigations are applied during this period, successful and reliable early predictions of the disease impact on grain yield would be very useful to growers in deciding whether it is worthwhile to keep applying management inputs to infected fields, or even parts of the field with lower disease severity levels and greater yield potential. The primary objective of the current project was to investigate whether early spring assessment of WSM severity levels could be used to predict final grain yields.

\section{Materials and Methods}

The first experiment was conducted during the 2012-13 wheat season in Bushland, Texas, under a center-pivot irrigation system. A strip of Karl 92 (9 m wide) was planted along the south edge of the field site in late July to serve as a trap crop for WCM and a point source of natural WSMV infection for the experimental field, which was planted on 10 September 2012. Soon after symptoms of the WSM began to develop on the southeast edge of the field, multiple $1 \mathrm{~m}^{2}$ (4 row) plots with uniform stands were established in arbitrarily selected locations both in symptomatic and nonsymptomatic areas of the field. The disease spread over time from the southeast to the northwest corner of the field, forming a severity gradient with relatively fewer symptomatic plants at the northwest corner. A total of 75 plots were marked, of which 15 at the northwest corner, with little or no disease symptoms, were used as controls.

Symptomatic leaf samples from both the trap strip and the research field were arbitrarily collected and tested for WSMV using ELISA. Disease severity (based on tissue reflectance) in each plot was assessed weekly, beginning 15 April when the crop was at Feekes growth stage of 5 to 6 (Large 1954), using a handheld hyperspectral radiometer (SD 2000, Ocean Optics, Dunedin, FL) at $555 \mathrm{~nm}$ band (yellow band region). Reflectance measurements were taken between 11:30 a.m. and 1:30 p.m. Others have used different wave lengths for disease assessments (Stilwell et al. 2013) but we have demonstrated previously that reflectance measurements at $555 \mathrm{~nm}$ are strongly correlated with visual ratings of WSM symptom severity and final grain yields (Workneh et al. 2009). The center two rows of each plot were hand-harvested for grain yield on 28 June 2013.

The second field experiment was conducted during the 2015-16 wheat season in a 118 -acre grower's field near Dalhart, Texas. The field was planted on 6 November 2015 to the cultivar TAM 304 and irrigated with a center-pivot irrigation system. Disease symptoms were first observed along the southwest edge of the field and spread northeast during the growing season with a declining severity gradient, i.e., the southwest edge was severely infected and symptomatic by late March, while the northeast side showed little or no infection as late as the end of May. As in the first study, $1 \mathrm{~m}^{2}$ plots (5 rows) were established in arbitrarily selected locations with uniform stands along the disease gradient southwest to northeast. A total of 114 plots were marked for WSM severity assessments across the field, and an additional 25 plots on the eastern edge of the field, with little or no visual symptoms of WSM, for use as healthy controls. Remotesensing data (reflectance values) from all plots were collected weekly beginning 27 April (Feekes growth stage scale of 5 to 6) with a handheld hyperspectral radiometer, as in the first experiment. Symptomatic leaves from 62 randomly selected plots were collected and tested for WSMV, TriMV, HPWMoV, and Barley yellow dwarf virus (BYDV) using ELISA. Finally, the center three rows of all plots were harvested for grain yield on 29 June 2016.

Analyses. The impact of WSM severity on grain yield was assessed relative to the mean grain weight of the control plots (standardized) described above. For analyses, grain weight values were transformed using square root transformation to homogenize the variances to better fit the model described below. All analyses were conducted using SAS software version 9.2 (SAS Institute Inc., Cary, NC). Preliminary graphical summaries of the relationship between reflectance values and yield appeared to follow a negative sigmoidal curve, which is normally best described by the logistic function (Brown and Rothery 1993). Thus, the data were fitted to the logistic function equation in the form of

$$
Y=a-b \times \exp (c(X-d)) /(1+\exp (c(X-d)))
$$

and analyzed using the nonlinear procedure, PROC NLIN, where $X$ and $Y$ represent reflectance values and relative grain yield, respectively. The symbol $a$ represents the intercept while $b, c$, and $d$ are model parameters. Psuedo $\mathrm{R}^{2}$, the term usually applied to the goodness of fit indicator for nonlinear models (Schabenberger and Pierce 2002; Zar 2010), was calculated from the analysis output as $R^{2}=1-$

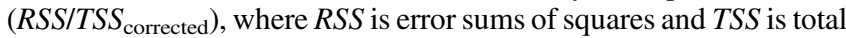
sums of squares corrected for the mean.

\section{Results}

For the 2013 study, all symptomatic samples collected from both the trap strip and the experimental field tested positive for WSMV. Also in 2016, all symptomatic samples tested positive for WSMV; however, in addition to WSMV, about $6.5 \%$ of the samples tested positive for TriMV (in association with WSMV), while none were positive for HPWMoV or BYDV, indicating that the dominant causal agent was WSMV.

Results from only the first three assessment dates are presented here. Results for the later dates would not be of any practical or significant economic value to growers because management practices are normally applied earlier in the spring in order to have a measurable impact on grain yield. The spectral profiles (400 to $800 \mathrm{~nm}$ ) of the first five contiguous wheat streak and control plots for both years (each represented by data from the second assessment date) are presented in Figure 1. At $555 \mathrm{~nm}$, WSMV-infected plants normally have
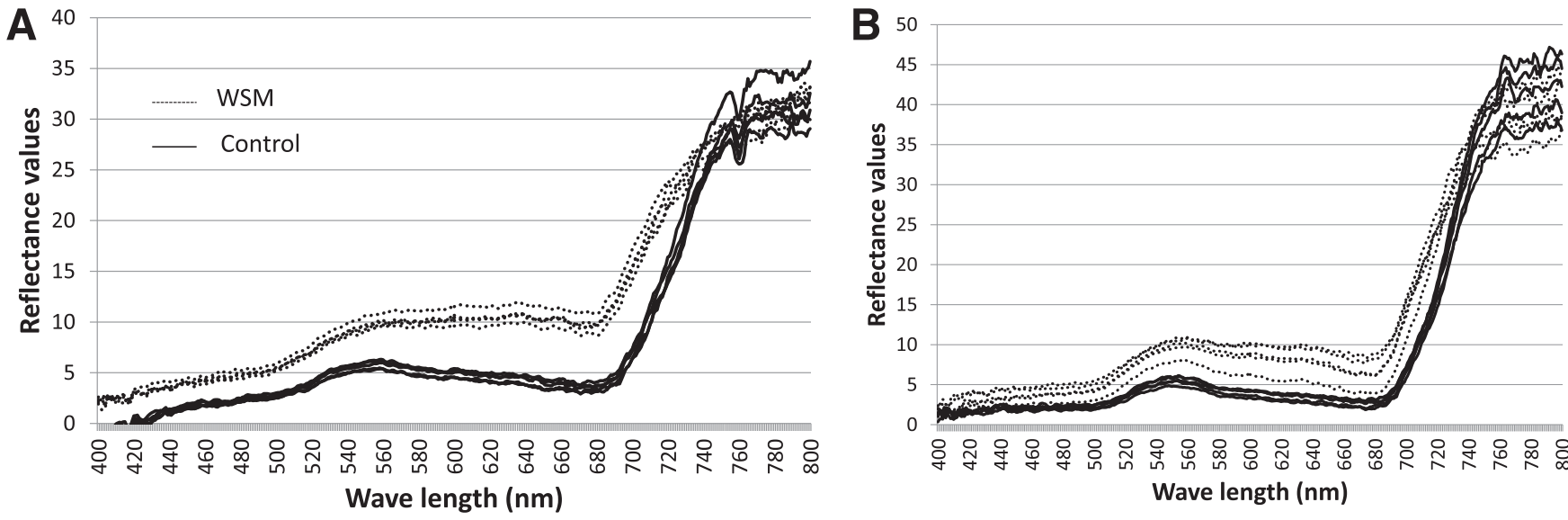

Fig. 1. Spectral profiles of wheat streak mosaic symptomatic plots (WSM) and of plots used as controls (control) for five contiguous plots for the 2013 (A) and 2016 (B) field assessments. 
greater reflectance values than noninfected plants (Workneh et al. 2009, 2010). Thus, in both years, as expected, reflectance values for the WSM assessment plots were distinctly higher than those of the control plots (Fig. 1).

For the 2013 study, individual reflectance values for the WSM assessment plots ranged from 4.7 to 14.2 for the three assessment dates. Mean reflectance values increased from 6.1 at the first assessment date to 9.1 at the third (Table 1). Plots used as reference points (controls) had overall reflectance values ranging from 4.5 to 7.8 with mean values ranging from 5.0 at the first assessment date to 7.1 at the third (summaries of reflectance and yield values are presented only in the text). As expected, overall reflectance readings of the controls plots were much lower than those of WSM assessment plots. Individual grain yield values for $2013 \mathrm{WSM}$ plots ranged from 0.00 to 95.0 with a mean value of $25.7 \mathrm{~g} / \mathrm{m}^{2}$ (Table 1 ), whereas plots used as controls had individual values ranging from 40.2 to 87.4 with a mean value of $64.9 \mathrm{~g} / \mathrm{m}^{2}$.

For the 2016 study, the overall reflectance values the WSM plots ranged from 3.8 to 13.0 , with mean values ranging from 6.8 at the first assessment date to 7.5 at the second (Table 2). For the control plots, individual reflectance values ranged from 4.2 to 10.1 , while the mean values ranged from 5.9 at the second to 6.6 at the first. Grain yields ranged from 45.7 to 736.4 with a mean value of $402.9 \mathrm{~g} / \mathrm{m}^{2}$ (Table 2). Control plots had yield values ranging from 381.3 to 670.0 , with a mean value of $487.2 \mathrm{~g} / \mathrm{m}^{2}$.

The relationships between WSM severity levels and grain values were well described by the logistic function in both years of the two-year study. For the 2013 study, $\mathrm{r}^{2}$ values were $0.71,0.75$, and 0.67 for the first, second, and third assessment dates, respectively (Figs. 2A, B, and C), all being highly significant $(P<0.0001)$. For the 2016 study, the relationships between disease severity and final grain yield were stronger than those in 2013 (Figs. 3A, B, and C), with $\mathrm{r}^{2}$ values of $0.81,0.81$, and $0.85(P<0.0001)$. Model parameter estimates, their standard errors, and $95 \%$ confidence limits for each assessment date for both are presented in Tables 3 and 4. For both years, the $95 \%$ confidence intervals for the parameter estimates were narrow with small standard errors indicating an overall good fit for the model. The relationship between reflectance values and yield followed a negative sigmoidal curve in all assessments, where yield values appeared to be flattened at extreme ends but showed a steep decline in the middle.

Table 1. Mean, minimum, maximum, and standard errors of reflectance values (Refl) for the three assessment dates and final grain yield for 2013 field experiment

\begin{tabular}{lccrccc}
\hline Date & Variable & $\mathbf{N}^{\mathbf{y}}$ & Mean & Min. & Max. & Std. error \\
\hline 15 April & Refl & 60 & 6.1 & 4.7 & 10.7 & 0.18 \\
22 April & Refl & 60 & 7.5 & 5.7 & 11.0 & 0.21 \\
29 April & Refl & 60 & 9.1 & 7.3 & 14.2 & 0.25 \\
& Yield $^{z}$ & 60 & 25.7 & 0.0 & 95.0 & 3.11 \\
\hline
\end{tabular}

${ }^{\mathrm{y}} \mathrm{N}$ represents number of plots.

${ }^{\mathrm{z}}$ Yield values are in grams $/ \mathrm{m}^{2}$.

Table 2. Mean, minimum, maximum, and standard errors of reflectance values (Refl) for the three assessment dates and final grain yield for 2016 field experiment

\begin{tabular}{lccrcrc}
\hline Date & Variable & $\mathbf{N}^{\mathbf{x}}$ & Mean & Min. & Max. & Std. error \\
\hline 27 April & Refl $^{\mathrm{y}}$ & 111 & 6.8 & 3.8 & 13.0 & 0.23 \\
4 May & Refl $_{\text {10 May }}$ & 113 & 7.5 & 4.8 & 12.0 & 0.17 \\
& Refl & 113 & 6.7 & 4.1 & 11.4 & 0.16 \\
& Yield $^{\mathrm{z}}$ & 111 & 402.9 & 45.70 & 736.4 & 18.88 \\
\hline
\end{tabular}

\footnotetext{
${ }^{\mathrm{x}} \mathrm{N}$ represents numbers of plots.

${ }^{y}$ One of the plots was run over by a tractor and reflectance (Refl) readings from two of them were not taken correctly.

${ }^{\mathrm{z}}$ Yield values are in grams $/ \mathrm{m}^{2}$.
}

In 2013, plots that had reflectance values of 8 or more on the first assessment date (15 April) failed to produce any grain yield (Fig. 2A). However, plots that had reflectance values of 8 a week later (22 April) produced some grain, although the amount was much less compared with those of the control plots (Fig. 2B). Furthermore, plots that had reflectance values of 8 on 29 April had relatively greater grain yield than plots with reflectance value of 8 at the previous two assessment dates, albeit still much less than the control plots with lower reflectance value (Fig. 2C). In 2016, relative grain yields for plots that had reflectance values of 8 on 27 April were similar to those in the 2013 study, assessed on 29 April (Fig. 3A). Relative yield levels increased slightly from the previous assessment date for plots that had reflectance values of 8 (Fig. 3B) on the 4 May assessment date but did not increase any higher at the following assessment date (10 May, Fig. 3C).
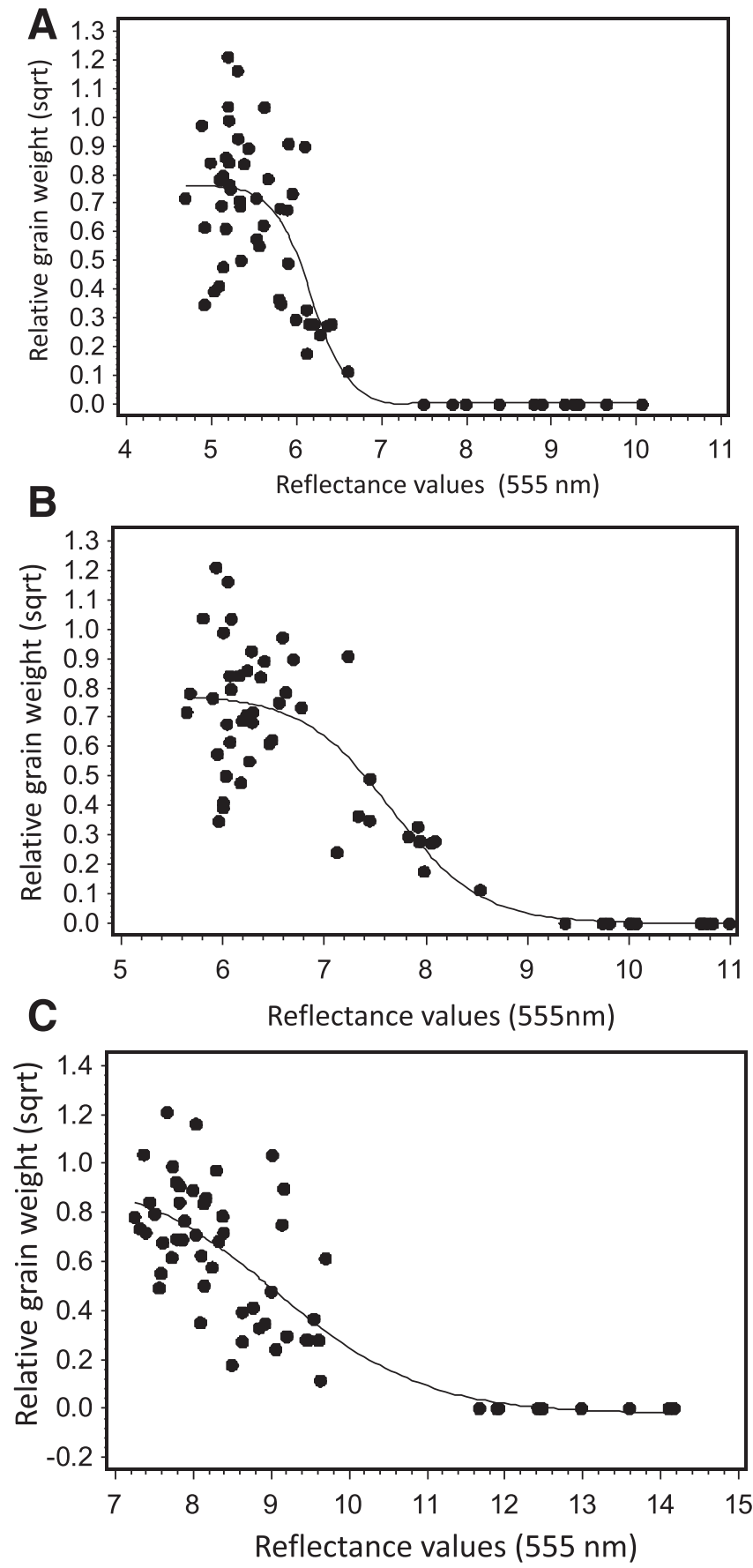

Fig. 2. Relationships between wheat streak mosaic severity (as expressed by reflectance values) and relative grain yield for assessment dates of 15 April (A), 22 April (B), and 29 April (C) 2013 
In the 2013 field study, reflectance values below 5.5 did not relate well to the yield values, especially for the 15 and 22 April assessment dates (Figs. 2A and B). It can easily be seen from the figures that plots with similar reflectance values had wide variability in relative grain yields. The 2016 field results are also similar to that of the 2013 in that below the reflectance value of 5.5, there were no apparent trends in relationships between reflectance values and relative grain yield. This is true for all the assessment dates (Figs. 3A, B, and C) for which the relative yield values did not change with changing reflectance values between 3.5 and 5.5 but remained clustered.

\section{Discussion}

Wheat streak mosaic is the most frequently observed wheat virus in the U.S. High Plains, including the Texas High Panhandle (Burrows et al. 2009; Byamukama et al. 2013; Workneh et al. 2008),

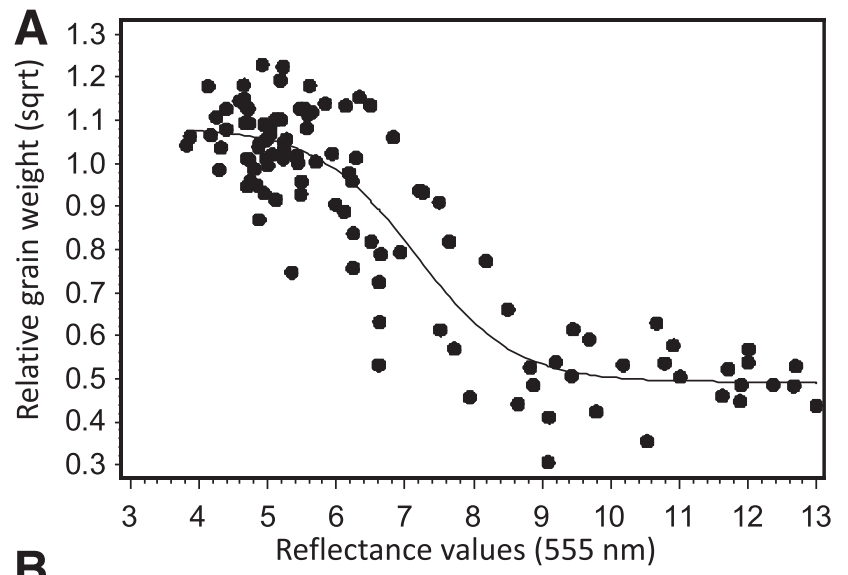

B
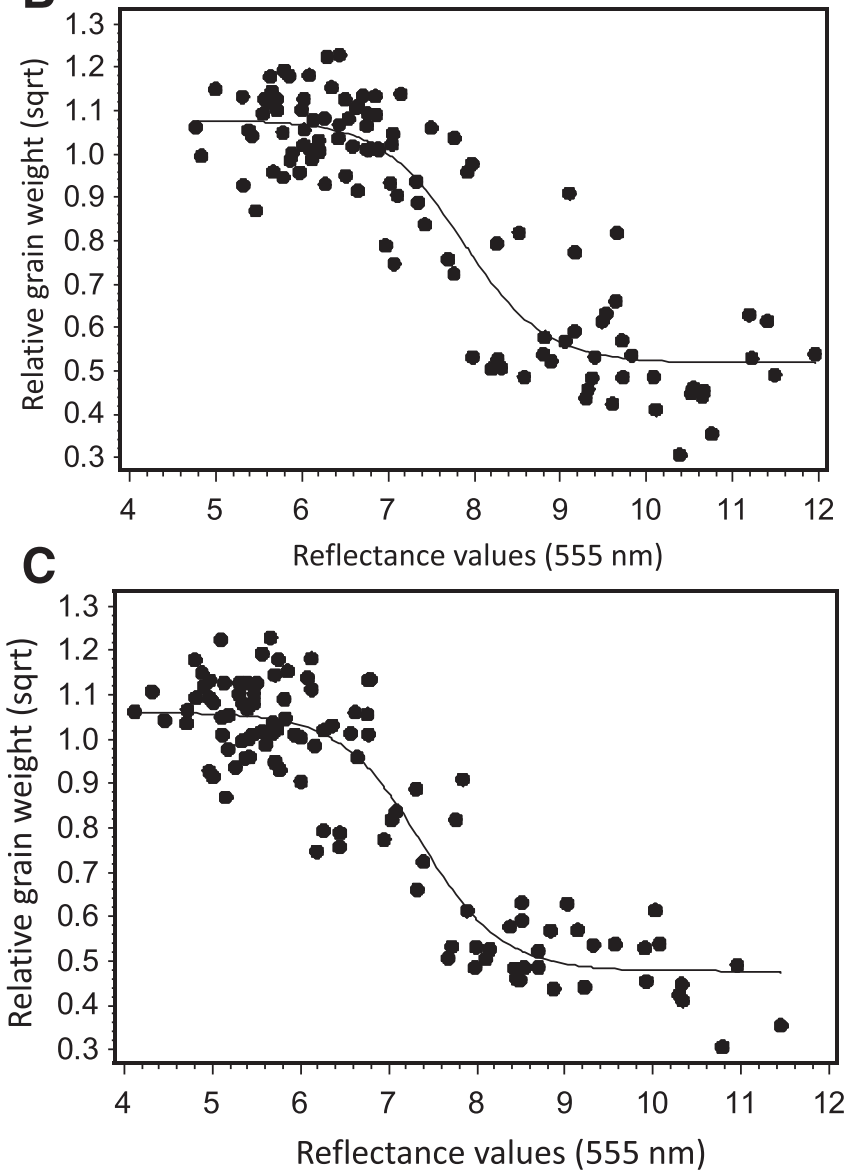

Fig. 3. Relationships between wheat streak mosaic severity (as expressed by reflectance values) and relative grain yield for assessment dates of 27 April (A), 4 May (B), and 10 May (C) 2016. and over the years the disease has caused periodic epidemics with significant losses (Almas et al. 2016; Byamukama et al. 2014; Velandia et al. 2010). Currently there are no pesticides registered for control of the mites on wheat, and when epidemics occur, growers have few options other than harvesting the field for hay, bringing in cattle and grazing it out, or plowing the field and replanting with other crops such as grain sorghum and short season corn. In addition, since WSM is spatially and temporally progressive, not knowing how much of the field will ultimately be affected by the disease or its final impact on grain yield greatly complicates management decisions for growers. Understanding how disease severity at any given time during the season ultimately relates to final yield would be of exceptional value to wheat farmers throughout the Great Plains. Many growers in the Texas Panhandle continue to apply crop inputs, such as insecticide applications, layby fertilization, and continued irrigation to their wheat crop into May. For example, the 2016 wheat field, although severely infected in significant parts of the field, continued to be irrigated until early June. Understanding how disease severity in late March through April impacts yield potential would allow more accurate cost/benefit analysis.

This two-year field study provided interesting and useful information in that the impact of WSM on final grain yield was reliably predicted from WSM severity early in the spring. In both years, the relationship between reflectance values and subsequent grain yield, relative to the controls, was well described by the logistic function model. The model was able to significantly predict relative grain yield from WSM severity levels for all assessment dates in both years, beginning as early as mid-April, a time when many crop inputs are still being applied.

Table 3. Parameter estimates, standard errors, and approximate $95 \%$ confidence limits for the 2013 wheat streak mosaic severity data fitted to the logistic function model for each of the three assessment dates

\begin{tabular}{|c|c|c|c|c|c|}
\hline \multirow[b]{2}{*}{$\begin{array}{l}\text { Assessment } \\
\text { date }\end{array}$} & \multirow[b]{2}{*}{ Parameter } & \multirow[b]{2}{*}{ Estimate } & \multirow[b]{2}{*}{$\begin{array}{c}\text { Std. } \\
\text { error }\end{array}$} & \multicolumn{2}{|c|}{$95 \%$ confidence limits } \\
\hline & & & & $\begin{array}{l}\text { Lower } \\
\text { limits }\end{array}$ & $\begin{array}{l}\text { Upper } \\
\text { limits }\end{array}$ \\
\hline \multirow[t]{4}{*}{15 April } & a & 0.7579 & 0.0748 & 0.6081 & 0.9077 \\
\hline & $\mathrm{b}$ & 4.6550 & 1.7145 & 1.2203 & 8.0896 \\
\hline & $\mathrm{c}$ & 0.7624 & 0.0427 & 0.6760 & 0.8479 \\
\hline & d & 6.1681 & 0.0866 & 5.9947 & 6.3416 \\
\hline \multirow[t]{4}{*}{22 April } & $\mathrm{a}$ & 0.7765 & 0.0819 & 0.6125 & 0.9405 \\
\hline & $\mathrm{b}$ & 2.2853 & 0.8381 & 0.6064 & 3.9642 \\
\hline & $\mathrm{c}$ & 0.7770 & 0.0500 & 0.6768 & 0.8772 \\
\hline & $\mathrm{d}$ & 7.6616 & 0.1694 & 7.3223 & 8.0009 \\
\hline \multirow[t]{4}{*}{29 April } & $\mathrm{a}$ & 0.9884 & 0.3047 & 0.3780 & 1.5988 \\
\hline & $\mathrm{b}$ & 1.0667 & 0.5928 & -0.1208 & 2.2541 \\
\hline & $\mathrm{c}$ & 0.9656 & 0.2559 & 0.4531 & 1.4782 \\
\hline & $\mathrm{d}$ & 9.0783 & 0.5133 & 8.0500 & 10.1066 \\
\hline
\end{tabular}

Table 4. Parameter estimates, standard errors, and approximate $95 \%$ confidence limits for the 2016 wheat streak mosaic severity data fitted to the logistic function model for each of the three assessment dates

\begin{tabular}{lccccc}
\hline & & & & \multicolumn{2}{c}{ 95\% confidence limits } \\
\cline { 5 - 6 } $\begin{array}{l}\text { Assessment } \\
\text { date }\end{array}$ & Parameter & Estimate & $\begin{array}{c}\text { Std. } \\
\text { error }\end{array}$ & $\begin{array}{c}\text { Lower } \\
\text { limits }\end{array}$ & $\begin{array}{c}\text { Upper } \\
\text { limits }\end{array}$ \\
\hline 27 April & $\mathrm{a}$ & 0.5903 & 0.0403 & 0.5105 & 0.6702 \\
& $\mathrm{~b}$ & 1.3948 & 0.2807 & 0.8383 & 1.9512 \\
& $\mathrm{c}$ & 1.0824 & 0.0269 & 1.0291 & 1.1356 \\
& $\mathrm{~d}$ & 7.1576 & 0.1783 & 6.8040 & 7.5111 \\
4 May & $\mathrm{a}$ & 0.5603 & 0.0414 & 0.4783 & 0.6423 \\
& $\mathrm{~b}$ & 2.1098 & 0.5508 & 1.0181 & 3.2015 \\
& $\mathrm{c}$ & 1.0782 & 0.0227 & 1.0333 & 1.1231 \\
& $\mathrm{~d}$ & 7.8688 & 0.1295 & 7.6121 & 8.1255 \\
& $\mathrm{a}$ & 0.5833 & 0.0374 & 0.5092 & 0.6575 \\
& $\mathrm{~b}$ & 2.1793 & 0.5053 & 1.1778 & 3.1809 \\
& $\mathrm{c}$ & 1.0601 & 0.0186 & 1.0233 & 1.0969 \\
& $\mathrm{~d}$ & 7.3629 & 0.1090 & 7.1469 & 7.5790 \\
\hline
\end{tabular}


Although overall there was a strong relationship between reflectance values and final grain yield, the relationship was not as strong when reflectance values were $\leq 5.5$, especially for the first assessment dates. This was not unexpected because reflectance values in this range are those of healthy or asymptomatic green tissue, with no evidence of infection by WSMV. Although there were variations in yield due to other intrinsic factors in plots with reflectance values $\leq 5.5$, there were no corresponding variations in reflectance levels. In this study, field plots were selected to cover all ranges of WSM severity levels (from severely infected to noninfected) for incorporation into the model. Consequently, at the first reflectance reading there were plots with mostly healthy green tissue that had grain yields comparable to or greater than those of plots used as controls, resulting in relative yield values of 1 or above. However, in the consecutive assessment dates, the reflectance values of some of these plots increased (in some cases up to 8 or above), suggesting that those plots either had infected but asymptomatic plants at the first reading, or got infected soon after the first reading and symptoms rapidly developed in association with warmer temperatures. Although it has long been recognized that early season infections result in the greatest yield loss (Hunger et al. 1992), disease severity assessments using remote sensing tools earlier than our assessment dates would have led to background contamination from the bare soil because the rows were not yet fully closed. However, we believe that the earlier the disease can be accurately measured, the more value the approach offers to growers. Initial disease assessments would have the greatest potential benefit if conducted as soon as temperatures begin to warm in the spring and the winter crop comes out of dormancy.

The observed differences in grain yield between the 2013 and 2016 studies (Tables 1 and 2), in addition to differences in WSM severity levels, could have resulted from any number of factors. Differences due to geographic location, regional weather, cultivars, and cultural practices are all generally recognized factors that could have accounted for the yield differences. However, there were two factors that definitely had significant impact on the yield differences. The $1-\mathrm{m}^{2}$ plots in the 2013 study contained 4 rows (planted to 10 -inch rows) and the center two rows were harvested for grain, while the 2016 field had five rows (planted to 7-inch rows) and the center three rows were harvested. In addition, the 2013 field was damaged by hail about a week before harvest, reducing the overall grain yields. Nonetheless, the use of standardized yield values (relative to those of the control plots) by comparing yields from infected and uninfected parts of the same field greatly diminished the effects of these differences. In addition, the standardization of the impact of the disease on yield enabled us to effectively fit data from the two separate fields (and years) into one model and be able to predict WSM impact on grain yield.

Two separate economic analyses conducted on experimental and growers' fields in the Texas Panhandle showed that WSM has highly significant impacts on profitability of wheat production in the region (Almas et al. 2016; Velandia et al. 2010). The studies specifically pointed out that irrigated wheat producers stand to lose the most from the disease because of the additional costs of irrigation and other inputs associated with a crop with higher yield potential. This loss is incurred primarily due to diminished returns from irrigation of infected plants in which water-use efficiency is significantly reduced by the disease (Price et al. 2010; Workneh et al. 2010). The current study predicted the impact of WSM severity on grain yield, beginning in April when growers are still adding inputs to maximize final yield. Early information on how much yield is expected at harvest is beneficial to growers for making decisions on whether to continue to irrigate and also add other inputs to infected fields. The disease is generally progressive over time, forming a severity gradient across the field (Workneh et al. 2009, 2010) and site-specific management applications can be made in parts of the fields where the disease is less severe and yield potential is higher. The commercial availability of variable rate irrigation (commonly known as VRI) with center pivot irrigation systems, in conjunction with remote disease detection (Mirik et al. 2011, 2013) and decision support systems such as that reported by O'Shaughnessy et al. (2016), now allow growers to implement site-specific management and reduce or eliminate irrigation of infected parts of a field with low yield potential. Site-specific management would be more effective if combined with the disease economic threshold (disease level above which it becomes unprofitable to irrigate or add any other inputs) based on predicted yield values.

\section{Acknowledgments}

Funding for this project was partially provided by the USDA-AFRI (201368004), the Southern Region IPM (2013-34103-21031), and the USDA-ARS Ogallala Aquifer Program. Funding also was provided by the Texas Wheat Producers Board. We would like to thank Jewel Arthur, Jared Bull, and Jimmy Gray for their technical assistance.

\section{Literature Cited}

Almas, L. K., Price, J. A., Workneh, F., and Rush, C. M. 2016. Quantifying economic losses associated with levels of wheat streak mosaic incidence and severity in the Texas High Plains. Crop Prot. 88:155-160.

Bowden, R. L., Brooks, H. L., Peterson, D. E., and Shroyer, J. P. 1991. Be a good neighbor: Control your volunteer wheat. Kansas State University, August 1991, MF-1004.

Brown, D., and Rothery, P. 1993. Models in Biology: Mathematics, Statistics, and Computing. John Wiley, New York.

Burrows, M., Franc, G., Rush, C., Blunt, T., Ito, D., Kinzer, K., Olson, J., O’Mara, J., Price, J., Tande, C., Ziems, A., and Stack, J. 2009. Occurrence of viruses in wheat in the Great Plains region, 2008. Online. Plant Health Prog. Online, doi:10.1094/PHP-2009-0706-01-RS

Byamukama, E., Seifers, D. L., Hein, G. L., De Wolf, E., Tisserat, N. A., Langham, M. A. C., Osborne, L. E., Timmerman, A., and Wegulo, S. N. 2013. Occurrence and distribution of Triticum mosaic virus in the central Great Plains. Plant Dis. 97:21-29.

Byamukama, E., Wegulo, S. N., Tatineni, S., Hein, G. L., Graybosch, R. A., Benziger, P. S., and French, R. 2014. Quantification of yield loss caused by Triticum mosaic virus and Wheat streak mosaic virus in winter wheat under field conditions. Plant Dis. 98:127-133.

Christian, M. L., and Willis, W. G. 1993. Survival of Wheat streak mosaic virus in grass hosts in Kansas from wheat harvest to fall wheat emergence. Plant Dis. 77: 239-242.

Connin, R. V. 1956. The host ranges of the wheat curl mite, vector of Wheat streak mosaic virus. J. Econ. Entomol. 49:1-4.

Fuentes-Bueno, I., Price, J. A., Rush, C. M., Seifers, D. L., and Fellers, J. P. 2011. Triticum mosaic virus isolates in the southern Great Plains. Plant Dis. 95: 1516-1519.

Hunger, R. M., Sherwood, J. L., Evans, C. K., and Montana, J. R. 1992. Effects of planting date and inoculation date on severity of wheat streak mosaic in hard red winter wheat cultivars. Plant Dis. 76:1056-1060.

Jensen, S. G., Lane, L. C., and Seifers, D. L. 1996. A new disease of maize and wheat in the High Plains. Plant Dis. 80:1387-1390.

Large, E. 1954. Growth stages of cereals: Illustrations of the Feek's scale. Plant Pathol. 3:128-129.

McGuire, V. L. 2006. Water-level changes in the High Plains aquifer, predevelopment to 2005 and 2003 to 2005 . USGS Scientific Investigation Report 2006-5324.

McMechan, A. J., Tatineni, S., and French, R. 2014. Differential transmission of Triticum mosaic virus by wheat curl mite populations collected in the Great Plains. Plant Dis. 98:806-810.

Mirik, M., Ansley, R. J., Price, J. A., Workneh, F., and Rush, C. M. 2013. Remote monitoring of wheat streak mosaic progression using sub-pixel classification of landsat 5 TM imagery for site-specific disease management in winter wheat. Adv. Rem. Sens. 2:16-28.

Mirik, M., Jones, D. C., Workneh, F., Ansley, J., and Rush, C. M. 2011. Satellite remote sensing of wheat infected by Wheat streak mosaic virus. Plant Dis. 95: 4-12.

O'Shaughnessy, S. A., Evett, S. R., Andrade, A., Workneh, F., Price, J. A., and Rush, C. M. 2016. Site-specific variable rate irrigation as a means to enhance water use efficiency. Trans. ASABE 59:239-249.

Pradhan, G. P., Xue, Q., Jessup, K. E., Hao, B., Price, J. A., and Rush, C. M. 2015. Physiological responses of hard red winter wheat to infection by Wheat streak mosaic virus. Phytopathology 105:621-627.

Price, J. A. 2015. Ecology and Epidemiology of Wheat streak mosaic virus, Triticum mosaic virus, and their mite vector in wheat and grassland fields. Ph.D. Thesis, Texas Tech University, Lubbock, TX.

Price, J. A., Simmons, A. R., Rashed, A., Workneh, F., and Rush, C. M. 2014 Winter wheat cultivars with temperature sensitive resistance to Wheat streak mosaic virus do not recover from early infections. Plant Dis. 98:525-531.

Price, J. A., Workneh, F., Evett, S., Jones, D. C., Arthur, J., and Rush, C. M. 2010. Effects of Wheat streak mosaic virus on root development and water-use efficiency of winter wheat. Plant Dis. 94:766-770.

Scanlon, B. R., Reedy, R. C., Gates, J. B., and Gowda, P. H. 2010. Impact of agroecosystems on groundwater resources in the Central High Plains, USA. Agric. Ecosyst. Environ. 139:700-713.

Schabenberger, O., and Pierce, J. F. 2002. Contemporary Statistical Models for the Plant and Soil Sciences. Taylor and Francis, New York. 
Seifers, D. L., Harvey, T. L., Martin, T., and Jensen, T. 1997. Identification of the wheat curl mite as the vector of the High Plains virus of corn and wheat. Plant Dis. 81:1161-1166.

Seifers, D. L., Martin, T. J., Harvey, T. L., Fellers, J. P., Stack, J. P., Ryba-White, M., Haber, S., Krokhin, O., Spicer, V., Lovat, N., Yamchuk, A., and Standing, K. G. 2008. Triticum mosaic virus: a new virus isolated from wheat in Kansas. Plant Dis. 92:808-817.

Seifers, D. L., Martin, T. J., Harvey, T. L., and Gill, B. S. 1995. Temperature sensitivity and efficacy of Wheat streak mosaic virus resistance derived from Agropyron intermideium. Plant Dis. 79:1104-1106.

Seifers, D. L., Martin, T. J., Harvey, T. L., and Haber, S. 2007. Temperature sensitive Wheat streak mosaic virus resistance identified in KS03HW-12 wheat. Plant Dis. 91:1029-1033.

Skare, J. M., Wijkamp, I., Denham, I., Rezende, J. A. M., Kitajima, E. W., Park, J., Desvoyes, B., Rush, C. M., Michels, G., Scholthof, K. G., and Scholhtof, H. 2006. A new eriophyid mite-borne membrane-enveloped virus-like complex isolated from plants. Virology 347:343-353.

Staples, R., and Allington, W. B. 1956. Streak mosaic of wheat in Nebraska and its control. University of Nebraska Agricultural Experiment Station, Research Bulletin 178.
Stilwell, A. R., Hein, G. L., Zygielbaum, A. I., and Rundquist, D. C. 2013. Proximal sensing to detect symptoms associated with wheat curl mitevectored viruses. Int. Remote Sens. 34:49514966.

Thomas, J. A., Hein, G. L., and Lyon, D. J. 2004. Spread of wheat curl mite and wheat streak mosaic virus is influenced by volunteer wheat control methods. Plant Health Prog. Online, doi:10.1094/PHP-2004-1206-01-RS

Velandia, M., Rejesus, R., Jones, D. C., Price, J. A., Workneh, F., and Rush, C. M. 2010. Economic impact of the Wheat streak mosaic virus in the Texas High Plains. Crop Prot. 29:699-703.

Workneh, F., Jones, D. C., Heidel, G. B., Price, J. A., and Rush, C. M. 2008. Surveys of wheat viruses in the Texas Panhandle. Phytopathology (Abstr.) 98:S173.

Workneh, F., Jones, D. C., and Rush, C. M. 2009. Quantifying wheat yield across the field as a function of wheat streak mosaic intensity: a state space approach. Phytopathology 99:432-440.

Workneh, F., Price, J. A., Jones, D. C., and Rush, C. M. 2010. Wheat streak mosaic: a classic case of plant disease impact on soil water content and crop water-use efficiency. Plant Dis. 94:771-774.

Zar, J. H. 2010. Biostatistical Analysis, 5th ed. Prentice Hall, Upper Saddle River, NJ. 